\title{
Tacitní znalosti jako most mezi teorií a praxí v pedagogické přípravě budoucích učitelů
}

\author{
Vlastimil Švec \\ Masarykova univerzita, Pedagogická fakulta, Katedra pedagogiky
}

Redakci zasláno 3. 6. 2012 / upravená verze obdržena 2. 9. 2012 / k uveřejnění přijato 9. 9. 2012

\begin{abstract}
Abstrakt: Studie si všímá tacitních znalostí v pedagogické prrípravě budoucích učitelů. Tyto znalosti chápe jako - metaforicky řečeno - most mezi teorií a praxí. Charakterizuje pojem tacitní znalosti, který u nás není dosud v pedagogické literatuře příliš frekventován. Tacitní znalosti jsou osobní, individuální znalosti, které vznikají na základě zkušeností subjektu a vyznačují se těmito rysy: jsou procedurální, ale obtížně navenek vyjádřitelné, jsou relevantní pro dosahování cílů, které subjekt považuje za důležité, vznikají jen s malou pomocí druhých nebo zcela bez této pomoci, jsou vázány na kontext. $\mathrm{V}$ pedagogické přípravě si je student učitelství osvojuje řešením praktických situací. Rozvoj a tedy i zdokonalování tacitních znalostí studentů předpokládá, že jsou tyto znalosti zexplicitněny. Nástrojem zexplicitnění je sebereflexe, avšak ta sama o sobě nestačí k tomu, aby si student uvědomil, jak jeho činnost vypadá a jak ji lze zlepšit. $\mathrm{K}$ tomuto cíli lze dospět sdílením zkušeností a tacitních znalostí studentů s kolegy a vzdělavatelem učitelů (cvičným učitelem na škole, oborovým didaktikem apod.).
\end{abstract}

Klíčová slova: teorie a praxe, tacitní znalosti, sebereflexe, sdílení tacitních znalostí, pedagogická praxe

\section{1 Úvod}

Problematika teorie a praxe v přípravě budoucích učitelů se u nás již mnoho let diskutuje s cílem nalézt jejich optimální obsah i proporci ${ }^{1}$. Shodně v těchto diskusích zaznívá konstatování, že významným zdrojem profesních znalostí studentů jsou jejich praktické zkušenosti. Dlouho se předpokládalo, že oporou pro tyto zkušenosti jsou pedagogické teorie prezentované studentům ještě před jejich pedagogickou praxí v akademických kurzech (předmětech).

1 Teorií budeme rozumět zobecněné empirické poznání pedagogické skutečnosti, utříděný soubor poznatků umožňující pochopit souvislosti reálných pedagogických jevů; praxí budeme označovat proces jednání, které se týká různých forem pedagogické činnosti (srov. Maňák, 2011, s. 258). 
Uvedený předpoklad se nepotvrdil ${ }^{2}$. Proto již před lety vznikaly pokusy zařazovat do akademické výuky budoucích učitelů aktivizující metody, mikrovyučování, reflexi atd. (viz např. Spilková, 2006; Lukášová, 2006; Švec \& Musil, 1999) se snahou přibližovat studentům praxi již v teoretických předmětech na fakultě.

Současně sejiž mnoho let diskutuje o poslání, rozsahua metodách pedagogické praxe zařazené do studijních programů učitelství (napřs. Janík \& Havel, 2005; Bendl, 2011). Stále však přetrvává určitá izolace mezi akademickou výukou na fakultách a pedagogickou praxí studentů na základních, popř. středních školách.

Hledají se také podněty pro propojování teorie a praxe v zahraničních modelech. Inspirací se u nás v posledních letech stává model tzv. realistického vzdělávání učitelů nizozemských autorů (Korthagen et al., 2011). Za inspirativní považujeme mj. tezi, že realistické vzdělávání budoucích učitelů začíná od konkrétních pedagogických problémů, s nimiž se studenti setkávají v reálné školní praxi. Studenti tyto problémy reflektují a diskutují se vzdělavatelem učitelů, přičemž postupně dochází ke konceptualizaci studentských zkušenostín.

Z tohoto modelu je také zřejmé, že reflexí pedagogických zkušeností studentů a jejich teoretickým zdůvodňováním a zobecňováním se postupně utvářejí pedagogické znalosti budoucích učitelů. Představují syntézu pedagogické teorie a praxe. Jsou to osobní znalosti studentů a na jejich utváření se podílí jejich sociální kontakt se vzdělavateli učitelů i s kolegy-studenty. Jde v něm o sdílení zkušeností i znalostí těchto účastníků.

Osobní pedagogické znalosti se projevují v jednání studentů učitelství ve třídě, avšak jejich základ je skrytý, tacitní. Tacitními znalostmi a jejich sdílením v pedagogické přípravě studentů učitelství se budeme zabývat v této stati. Kořeny jejího vzniku spadají do období před téměř deseti lety, kdy jsme řešili

2 Tento poznatek vyplynul z empirických zkušeností vzdělavatelů učitelů na více pedagogických fakultách (byly prezentovány na řadě konferencí a seminářů $\mathrm{k}$ učitelskému vzdělávání, jichž se autor této studie zúčastnil). Výzkumně je podložen např. dlouhodobým sledováním studentů učitelství v průběhu jejich studia na pedagogické fakultě a v prvním roce jejich praxe na škole (Švec, 2002).

3 Podrobněji se čtenář může seznámit s úrovněmi tohoto profesního učení budoucích učitelů, počínaje úrovní gestaltů, přes úroveň schémat až po úroveň teorie v citované publikaci nizozemských autorů i ve studii Slavíka et al. (2012), uveřejněné v tomto čísle Pedagogické orientace. 
grantový projekt GA ČR Implicitní pedagogické znalosti a možnosti autoregulace procesu jejich rozvíjení (406/02/1247). Dospěli jsme v něm mj. k modelu zkušenostního učení, který zahrnuje tyto prvky:

- pokus studenta jednat v pedagogické situaci;

- sdílení zkušeností z řešení situace s kolegy-studenty s využitím zpětné vazby od vzdělavatele učitelů;

- $\quad$ sebereflexi studentů;

- hledání dynamiky jednání studenta (tj. kontrastů mezi tím, co již student zná a co ještě nezná, aby danou situaci vyřešil);

- opakovaný pokus studenta o alternativní jednání (Švec, 2005, s. 34-35)

Dosud se všeobecně předpokládá, že pro rozvoj praktických zkušeností a tacitních znalostí jsou rozhodující délka a obsah praxe. Literatura si všímá tacitních znalostí spíše u zkušených profesionálů a expertů (Cianciolo et al., 2006; Píšová, 2010). Základy tacitních znalostí se však vytvářejí mnohem dříve, ještě v době přípravy studenta na profesní dráhu. Této problematice se dosud nedostává žádoucí pozornosti, i když jsou srovnávány znalosti expertů a začátečníků (noviců).

Cílem této stati je navázat na uvedené poznatky a zkušenosti, charakterizovat tacitní znalosti, objasnit jejich vztah k explicitním znalostem a na př́kladech ukázat možnosti sdílení tacitních znalostí v pedagogické př́ípravě budoucích učitelů. Tím se zároveň pokusit alespoň naznačit, že sdílení tacitních znalostí je jednou z cest, jak spojovat pedagogickou teorii s pedagogickou praxí.

4 Naznačený model se podobá ALACT modelu, který zahrnuje tyto elementy: jednání studenta, zpětný pohled na jednání, uvědomění si podstatných aspektů, vytvoření alternativních postupů jednání a vyzkoušení těchto postupů (Korthagen et al., 2011, s. 135). Tyto dva modely vznikly nezávisle na sobě. Podobně jako nizozemští autoři jsme dospěli k poznatku, že ucelené pedagogické teorie (např. teorie motivace, teorie výukových metod apod.) prezentované budoucím učitelům na fakultách před jejich pedagogickou praxí nepředstavují potřebné zázemí pro aplikaci v praxi. Užitečné jsou spíše „kousky“ teorií, které umožňují, aby studenti porozuměli praktickým pedagogickým situacím, s nimiž se setkali při výuce ve třídě (viz též Drever \& Cope, 1999). 


\section{Vymezení obecnějších východisek}

\subsection{Pojem tacitní znalosti ${ }^{5}$}

Vznik pojmu tacitní znalosti je spojen se jménem M. Polanyiho, který jejich podstatu vyjádřil ve zkratce: „Víme více, než můžeme říci“ (Polanyi, 1966, s. 4). To, co nedovedeme říci, má tacitní (skrytý) charakter. Tacitní znalosti jsou osobní, vznikají na základě zkušeností subjektu a lze je obtížně vyjádřit.

Sternberg, který z Polanyiho vycházel a zkoumal se spolupracovníky tacitní znalosti profesionálů z různých oborů (viz např. Sternberg \& Horvath, 1999), definoval tyto znalosti následujícími znaky (Sternberg, 2004, s. 271):

- jsou procedurální, ale zároveň obtížně navenek vyjádřitelné;

- jsou relevantní pro dosahování cílů, které subjekt považuje za důležité;

- $\quad$ subjekt jich dosahuje jen s malou pomocí druhých nebo zcela bez této pomoci;

- jsou vázány na kontext.

Sternberg (1999, s. 233-234) upozornil na to, že tacitní znalosti si subjekt osvojuje účinně zejména $\mathrm{v}$ prostředí, kde tyto znalosti bude potřebovat, a v prostředí, které podporuje zkoumání a podněcuje kritické myšlení. V tomto prostředí jsou př́ležitostí k osvojení tacitních znalostí spíše neobvyklé situace než běžné situace.

\subsection{Vztah tacitních a explicitních znalostí}

Tacitní znalosti se projevují v praktické činnosti studentů a profesionálů. Tuto činnost lze pozorovat a také posuzovat její kvalitu. Problém nastává, když si např. chce student nebo začátečník, popř. i méně zkušený profesionál osvojit tacitní znalosti od zkušeného odborníka, experta. $V$ činnosti experta, kterou lze sice pozorovat, není obvykle viditelné pozadí jeho profesionálního výkonu. To znamená, že tacitní znalosti nelze zcela převést do explicitní podoby.

5 V této části stati se omezujeme pouze na vybrané studie k problematice tacitních znalostí. Mnoho studií o tacitních znalostech se týká oblasti managementu, ekonomie a organizačního učení. V tomto smyslu odkazujeme zájemce na monografii Gregara et al. (2011). 
Znalosti, které jsou zjevné, artikulovatelné (lze je vyjádřit slovy, čísly, symboly, pohyby těla apod.) jsou označovány jako explicitní. Nejsou protikladem tacitních znalostí, spíše vyjadřují jejich komplementární protipól. Oba póly (tacitní a explicitní) jsou krajními body kontinua zahrnujícího řadu mezistupňů 6 . V pozorovatelné činnosti se tyto mezistupně sice projevují, ale nelze v nich jasně rozlišit, co je tacitní a co explicitní.

Tacitní a explicitní bychom proto mohli chápat jako dva aspekty činnosti, resp. výkonu. Čím více je výkon explicitní (tj. když víme, jak je strukturován), potom tím více můžeme s touto projevenou znalostí operovat, např ji převést do koherentního souboru výroků, které pak lze ověřovat (explicitní má blízko $\mathrm{k}$ teoretickému). A naopak, čím méně je ve výkonu explicitního, tím méně můžeme praktickou zkušenost teoretizovat (tacitní má blízko k praxi) ${ }^{7}$.

Snahy „převést“ tacitní znalosti v explicitní znalosti mají řadu důvodů. Zmíníme z nich jen dva podstatné:

- zexplicitnění tacitních znalostí umožňuje posuzovat kvalitu výkonu profesionála;

- zexplicitněné tacitní znalosti zkušeného odborníka (učitele, experta) jsou významným zdrojem profesního učení studentů (noviců).

V literatuře jsou popsány různé způsoby, jak učinit tacitní znalosti (resp. jejich část) explicitními. Závisí to do značné míry na charakteru tacitních znalostí. Psychomotorické tacitní znalosti vyžadují k zexplicitnění např. kombinaci videozáznamu, demonstrace činnosti odborníkem (expertem), animovaných obrázků a dialogu s expertem. $\mathrm{K}$ učení sociálně komunikativních tacitních znalostí se nabízí vedení studenta zkušeným učitelem, sebereflexe studenta a supervize. Nikkanen a Kantola (2008) uvádějí na základě analýzy mnoha literárních pramenů výčet dalších prostředků, které usnadňují zexplicitnění tacitních znalostí, např. metafory, analogie, videozáznam, animované obrázky, cvičení, diskuse ve skupině, narativní postupy a další.

Zexplicitnění tacitních znalosti je v řadě případů motivováno potřebou zvýšit výkon profesionálů a zisk organizací (firem), zkvalitnit služby, navrhnout a realizovat inovace, zkvalitnit týmovou práci ve výzkumu i praxi apod. Pro-

6 V běžném životě, ale mnohdy i v profesních situacích uvažujeme v dichotomiích: dobréšpatné, pozitivní-negativní apod. To nás často vede $\mathrm{k}$ jednostrannému vidění jevů a situací.

7 Tato úvaha je inspirována Mgr. Radimem Šípem, Ph.D. z katedry sociální pedagogiky PdF MU, s nímž jsem vedl diskuse o filozofickém zázemí tacitních znalostí. 
tože základem řešení profesních problémů i výuky ve skupinách je týmová spolupráce, všimněme si zexplicitňování tacitních znalostí členů týmu. Mascitelli (2000) považuje za klíčovou podmínku úspěšného využívání tacitních znalostí a zkušeností členů projektového týmu jeho klima a vzájemnou komunikaci face-to-face. Konkretizací těchto podmínek je následující přehled aktivit, za které zodpovídá vedoucí týmu (manažer; Mascitelli, 2000, s. 186): Vytváření pozitivní identity projektového týmu

- probuzení a udržení sociální identifikace členů týmu s vysokým týmovým výkonem;

- motivace členů týmu jasným stanovením jeho významu, jedinečnosti a potenciálu pro úspěch;

- posilování smyslu pro dobrodružství a objevení nečekaných možností při vývoji produktu.

Vytváření prostředí pro sdílení tacitních znalostí

- poskytnutí dostatečné jednoznačnosti v prvních fázích řešení projektu, která podporuje tvưrčí myšlení;

- užití metafor a analogií při sdělování strategické vize projektu;

- eliminace negativních zkušeností členů týmu při vyjadřování jejich vizí;

- kultivování prostředí respektu, rovnosti, tolerance, pečlivosti a vzájemného povzbuzování.

Nonaka a Takeuchi (1995) motivovaní potřebou využít tacitního potenciálu lidí při inovacích ve firmách navrhli, ověřili a zavedli do praxe čtyřfázový model konverze tacitních znalostí v explicitní a naopak (viz tabulka 1$)^{8}$.

8 Konverzí rozumíme přeměnu (změnu) tacitních znalostí ve znalosti explicitní a naopak, a to při týmovém řešení problémů. $V$ procesu konverze může docházet k rozvoji tacitních znalostí členů týmu. 
Tabulka 1

Fáze konverze tacitních znalostí podle Nonaky a Takeuchiho

\begin{tabular}{|c|c|c|c|}
\hline Název fáze & Úroveň znalostí & Podstata fáze & Charakteristika fáze \\
\hline Socializace & tacitní & $\begin{array}{l}\text { přímé „předání" } \\
\text { tacitních znalostí } \\
\text { prostřednictvím } \\
\text { sdílených } \\
\text { zkušeností }\end{array}$ & $\begin{array}{l}\text { ve vzájemné komunikaci subjekty } \\
\text { sdílejí své zkušenosti (pozorováním, } \\
\text { imitací, praktickou činností), } \\
\text { dochází k vytváření a „výměně“ } \\
\text { tacitních znalostí mezi subjekty }\end{array}$ \\
\hline Externalizace & tacitní-explicitní & $\begin{array}{l}\text { proces artikulace } \\
\text { tacitních znalostí } \\
\text { do formy znalostí } \\
\text { explicitních }\end{array}$ & $\begin{array}{l}\text { subjekty vyjadřují tacitní znalosti } \\
\text { v explicitní formě tak, aby jim } \\
\text { porozuměli ostatní }\end{array}$ \\
\hline Kombinace & explicitní & $\begin{array}{l}\text { proces uspořádání } \\
\text { dílčích znalostí } \\
\text { do znalostního } \\
\text { systému }\end{array}$ & $\begin{array}{l}\text { subjekty kombinují a integrují různé } \\
\text { explicitní znalosti a vytvářejí tak } \\
\text { jejich systém, dochází také ke sdílení } \\
\text { znalostí }\end{array}$ \\
\hline Internalizace & explicitní-tacitní & $\begin{array}{l}\text { proces přeměny } \\
\text { explicitních } \\
\text { znalostí ve znalosti } \\
\text { tacitní }\end{array}$ & $\begin{array}{l}\text { subjekty identifikují své explicitní } \\
\text { znalosti využitelné uvnitř } \\
\text { komunity (týmu) a zvnitřňují je } \\
\text { prostřednictvím praktické činnosti } \\
\text { (nácviku a cvičení) }\end{array}$ \\
\hline
\end{tabular}

Pozn.: upraveno dle Švec (2011a, s. 17).

V tabulce naznačený přechod tacitních znalostí v explicitní není ve skutečnosti tak přímočarý, nebot' jde o cyklický proces, který se odvíjí po spirále a je složitější, než jak jej popisují Nonaka a Takeuchi. Jednotlivé fáze se překrývají, někdy se vracejí a znovu - na jiné úrovni - probíhají.

\subsection{Sdílení tacitních znalostí}

V předcházející části textu jsme upozornili, že sdílení tacitních znalostí je nástrojem jejich zexplicitnění. Sdílení znalostí se obvykle (zejména v literatuře z oblasti znalostního managementu) chápe jako výměna informací (Ipe, 2003), resp. jako odevzdávání a přijímání znalostí mezi dvěma či více subjekty (de Vries, van den Hooff, \& de Ridder, 2006). Považujeme uvedené vymezení sdílení znalostí za zúžené, nebot' jeho smyslem je nejenom znalosti (přesněji informace) vyměňovat, ale také využívat při společném (např. týmovém) řešení problémů. Takto vznikají i nové znalosti. 
Pokud uvažujeme o sdílení tacitních znalostí, máme na mysli, že ve dvojici nebo skupině více subjektů se řeší problém nebo dochází k učení různě zkušených jedinců. Sdílení tacitních znalostí posiluje komunikace face-to-face (Nikkanen \& Kantola, 2008). V procesu sdílení tacitních znalostí se v různém pořadí (záleží na vstupní úrovni zkušeností subjektů) realizují fáze uvedené v tabulce 1 .

Proces sdílení ve skupině (týmu) řídí její facilitátor, jímž může být např. projektový manažer, vedoucí organizace nebo jejího oddělení, učitel, instruktor apod. Facilitátor podněcuje subjekty k pozorování činnosti, kterou realizuje jeden z nich, zapojuje postupně do činnosti další subjekty, vytváří prostředí spolupráce, vybízí k sebereflexi a k výměně reflektovaných zkušeností členů skupiny (Durrance, 1998).

\section{Tacitní znalosti a jejich sdílení v pedagogické přípravě studentů učitelství}

Předpokládejme, že již osvojené tacitní znalosti studenta učitelství se v pedagogické situaci částečně exteriorizují ve znalosti explicitní, které tvoří základ pozorovatelného jednání. $V$ tomto jednání se dřívější zkušenost (tacitní znalost) studenta mění vlivem podmínek (často neočekávaných) dané situace v novou zkušenost, a tedy i v novou tacitní znalost. Explicitní znalosti můžeme tedy považovat za vyjádření tacitního poznání studenta a zároveň za zdroj jeho nového tacitního poznávání.

Student se však v průběhu studia setkává s explicitními znalostmi vyprodukovanými jinými subjekty, např autory učebnic, odborných studií apod. Produktivita využití těchto explicitních znalostí závisí na dosavadních zkušenostech (tacitních znalostech) studenta. Pokud předkládané explicitní znalosti nejsou v souladu se zkušenostmi studenta, produktivita jejich využití je nízká. Student těmto znalostem nerozumí a dál se jimi nezabývá nebo si je osvojí pamětně. Jestliže však student disponuje zkušenostmi, které odpovídají předloženým explicitním znalostem, potom lze předpokládat, že tyto znalosti budou produktivně využity. Student např. může prostřednictvím nich více porozumět svým zkušenostem. Vhodně strukturované explicitní znalosti mohou dokonce tvořit východisko pro hlubší teoretické studium dané problematiky. 
Student učitelství si osvojuje různé druhy tacitních znalostí. Lze předpokládat, že tyto znalosti mají různou důležitost pro zdokonalování studentova jednání v pedagogických situacích ve třídě. Vzdělavatele učitelů zajímají především tzv. „užitečné tacitní znalosti“, které řídí studentovo jednání v souladu s jeho intencemi a cíli výuky.

\subsection{Sebereflexe studentů učitelství jako nástroj zexplicitnění tacitních znalostí}

Opakovaně se - v souvislostmi s tacitními znalostmi - poukazuje na to, že nedovedeme plně vyjádřit to, co děláme, jak nebo proč to děláme, a zda to, co děláme, děláme úspěšně (Burbules, 2008, s. 669). To znamená, že tacitní znalosti nelze sebereflexí zcela zexplicitnit. Přesto považujeme sebereflexi za jeden $\mathrm{z}$ užitečných nástrojů částečného zexplicitnění tacitních znalostí studentů učitelství.

Smyslem sebereflexe je, aby si student učitelství uvědomil ${ }^{9}$ :

- $\quad$ co, jak a proč dělal;

- jaký to mělo účinek na žáky;

- že existuje více možností, jak určitou situaci řešit;

- kde jsou jeho silná a slabší místa, která lze zlepšit („vyztužit“).

Účinek sebereflexe se posiluje, když mohou studenti učitelství posuzovat své zkušenosti (po akci) s odstupem a konfrontovat své reflektivní výpovědi (zkušenosti) s výpověd'mi svých kolegů a s pohledem cvičného učitele. Sebereflexi tacitních znalostí usnadňují tři distance od studentových zkušeností (Bengtsson, 1993):

- první distancí je, když se student učitelství distancuje od vlastní praktické činnosti, nahlíží ji při sebereflexi jakoby zvenčí; vyjevují se jeho tacitní znalosti, které dávají smysl reflektovaným činnostem;

- další distancí jsou reflexe studentovy činnosti jeho kolegy nebo vzdělavatelem učitelů; jde o vzájemný dialog mezi nejméně dvěma subjekty,

\footnotetext{
Uvědomováním si (něčeho) rozumíme „zvýznamnění, tj. nalezení výrazu pro obsah, který předtím ve vědomí nebyl zřetelně přítomen. Když si člověk něco uvědomí, musí to mít v mysli bud' jako pojem (tj. výraz s odpovídajícími významy), anebo jako představu (tj. smyslový obraz s odpovídajícími významy), ale v obou př́ípadech jde o sdělitelnou entitu." (Slavík, 2009).
} 
které mají podobnou zkušenost, at' již z hlediska obsahu praktické činnosti (např. motivace žáků), nebo z hlediska její úrovně (např. cvičný učitel - student učitelství);

- třetí distancí je vědecký výzkum praktické činnosti studentů, který přináší objektivní znalosti o praxi.

(Sebe)reflexí činnosti studenta v pedagogické situaci se vyjevují nejenom tacitní, ale i explicitní znalosti.

\subsection{Sdílení tacitních znalostí studentů s jejich vzdělavateli}

Sebereflexe studentů je významnou součástí utváření a zdokonalování jejich tacitních znalostí. Sama o sobě však nestačí k tomu, aby si student jasněji uvědomil, jak zaujal žáky, co se mu podařilo, co může zlepšit apod. Nezbytná je zpětná vazba od vzdělavatelů učitelů i od kolegů-studentů. Sdílení je př́ležitostí, jak posílit individuální náhled studenta na vlastní činnost. $\mathrm{Na}$ některé možnosti sdílení znalostí v pedagogické přípravě studentů učitelství jsme upozornili v samostatné studii (Švec, 2009a).

Na první pohled by se mohlo zdát, že tacitní znalosti mohou mezi sebou sdílet pouze studenti, protože mají podobnou úroveň pedagogických zkušeností, zatímco vzdělavatelé učitelů (předpokládejme, že to jsou zkušení cviční učitelé, oboroví didaktikové a ostatní akademičtí pracovníci, kteří vyučují pedagogické a psychologické předměty) disponují širším a hlubším repertoárem zkušeností. Tento pohled lze korigovat následujícími skutečnostmi:

- sdílení nespočívá pouzeve vzájemné konfrontacia výměněpedagogických zkušeností, ale také ve vytvoření prostoru (spíše intelektuálního) pro společné hledání možností, jak pedagogickou činnost, a tedy i tacitní znalosti studenta zdokonalit a dát jim teoretický základ;

- vzdělavatelé se mohou učit i od svých studentů.

Vzdělavatel učitelů v procesu sdílení nevede studenta direktivně, stojí jako by „V pozadí", ale zároveň je studentovi na blízku, nepodává instrukce a rady (jen jestliže to studentova činnost nezbytně vyžaduje, např. když je v nesnázích), nehodnotí, nekritizuje, nýbrž poskytuje - slovy Ivana Vyskočila - vstřícnou pozornost ke studentovu jednání1 ${ }^{10}$. Upozorňuje studenta, aby si všiml té či

10 Vstř́ícná pozornost je termín I. Vyskočila převzatý z tzv.psychosomatických disciplín (Švec, 2008). Znamená, že učitel se soustřed'uje na vnímání aktéra (studenta), zaujímá divácký postoj k jeho jednání (srov. Hančil, 2010). 
oné skutečnosti, vybízí ho, aby hledal alternativní řešení vzniklé situace apod. Snaží se vidět rozvoj studenta spíše z jeho perspektivy než z perspektivy své. To je obtížné, protože zkušený vzdělavatel disponuje většími a hlubšími pedagogickými zkušenostmi i teoretickými znalostmi než student a má přirozenou tendenci zasahovat studentovi do jeho aktivit s cílem mu pomoci.

Ke sdílení tacitních znalostí mohou přispět různé formy pedagogické př́ípravy. Užitečnou formou sdílení je tzv. co-teaching, který spočívá ve společném vyučování, např. studentů učitelství, studenta učitelství a vzdělavatele učitelů. Co-teaching je společnou žitou zkušeností, sdíleným porozuměním (Tobin \& Roth, 2006, s. 3, 33). Např́klad vzdělavatel učitelů se studentem učitelství spolu vyučují, a to tak, že určitou část hodiny vede vzdělavatel, v její další části vyučuje student. To znamená, že student přebírá vedení výuky od vzdělavatele, aniž by „pustil společnou štafetu“ (tj. společně vymezené cíle výuky i výukové metody). Tato forma sdílení je vhodná především pro pedagogické praxe. $V$ akademických předmětech lze uplatnit např. mikrovyučování.

\subsection{Pedagogická praxe jako optimální prostor pro sdílení tacitních znalostí}

Jedním ze stěžejních předmětů v přípravném vzdělávání učitelů je pedagogická praxe. Je většinou založena na pozorování pedagogické reality ve školách a na pedagogických výstupech, při nichž se studenti učitelství učí vyučovat žáky v reálných podmínkách třídy. Stále ještě přetrvává domněnka (i mezi mnohými vzdělavateli budoucích učitelů), že studenti, kteří většinou ještě nedisponují pedagogickými zkušenosti, mohou při hospitacích „něco“ vidět, slyšet a tím poznat a pochopit, jak má výuka vypadat. Toto poznání pak aplikují při vlastních pokusech vyučovat. Ve skutečnosti však jde o nápodobu, reprodukci určitého výsledku, tedy něčeho „nevlastního“ (Švec, 2009b, s. 411). Podobně Shulman (1998) upozorňuje, že pozorování výuky a hraní rolí nemůže nahradit autentické ponoření studentů do učitelské profese, na kterou se připravují.

Požadavek na sdílení tacitních znalostí studenta se vzdělavatelem klade nové nároky - časové a zejména didaktické - na pedagogické praxe. Na tomto místě nelze podat univerzální „návod“, jak toto sdílení uskutečňovat, ani podrobněji probírat postupy, které se nabízejí, spíše lze jen naznačit, jakým směrem by se mohly úvahy o propojování teorie a praxe ubírat. 
Všimněme si obvyklé situace, kdy vzdělavatel - cvičný učitel pozoruje pedagogickou činnost studenta ve vyučovací hodině. Následující komentáře cvičného učitele $\mathrm{k}$ výkonu studenta a jeho sebereflexe mohou být užitečné, avšak neposkytují prostor pro skutečné sdílení. Představme si nyní situaci, kdy student a vzdělavatel - cvičný učitel navzájem hospitují ve vyučovacích hodinách, které se vztahují ke stejnému ročníku, předmětu a tématu. Užitečné je, když existuje možnost nahrát obě hodiny nebo alespoň jejich části (na kterých se student a cvičný učitel domluví) na videozáznam. Po odučené hodině student provede sebereflexi a zachytí její obsah písemně. Poté lze diskutovat před obrazovkou o jednotlivých částech vyučovacích hodin a srovnávat postupy studenta a cvičného učitele. Nejde přitom o to, zjistit, že zkušený cvičný učitel „to či ono dělal lépe“, ale spíše, aby student porozuměl, proč učitel zvolil určitý postup. Aby student porozuměl „pozadí“, ze kterého vyrůstá učitelova činnost, tedy aby alespoň částečně pronikl do jeho tacitního poznání. Potom může student projít svoji napsanou reflexi a popř. ji doplnit ${ }^{11}$.

Sdílení zkušeností a tacitních znalostí (u studenta vytvářených, u cvičného učitele již usazených a stále rozvíjených) by mělo tvořit významnou součást pedagogických praxí. Student následuje cvičného učitele, nenapodobuje ho (zpočátku možná jen částečně; opakovaně si však - i napodobováním procvičuje technické znalosti, např. psaní na tabuli, práci s předepsanou dokumentací apod.), nýbrž se pokouší dostat pod povrch jeho jednání. Protože zkušený cvičný učitel nemůže plně artikulovat svoje tacitní znalosti, nabízí se možnost, aby se ho studenti dotazovali, např. na to, proč uplatnil určitý vyučovací postup, co ho k tomu vedlo, zda by bylo možné postupovat jinak apod. Kromě rozhovoru se nabízejí k zexplicitnění tacitních znalostí cvičných učitelů další postupy, např. psané sebereflexe cvičného učitele, jeho konceptuální mapy, stimulované vybavování před obrazovkou atd. (viz např. Zanting, Verloop, \& Vermunt, 2003).

Zexplictňované tacitní poznání cvičného učitele zahrnuje nejenom pól tacitní, ale i komplementární pól explicitní. Je tedy také zdrojem teoretického poznání, které může být rozvíjeno a doplňováno i syntetizováno v akademických předmětech na fakultě. Do sdíleného poznávání v průběhu pedagogické praxe

11 Na podobný způsob sdílení mezi zkušenou učitelkou a začínající učitelkou jsme upozornili již dříve (Švec, 2005, s. 35-36). Jedná se o formu „přebírání zkušeností“, tzv. učednictví (apprenticeship). 
mohou (měli by, musí) vstupovat oboroví didaktikové, ale také např. učitelé pedagogických a psychologických předmětů.

\section{Závěry a perspektivy výzkumu tacitních znalostí studentů učitelství}

Pokusili jsme se naznačit, že sdílení tacitních znalostí v pedagogické přípravě budoucích učitelů může přispět $\mathrm{k}$ posilování sepětí mezi teorií a praxí. Tacitní znalost svou polaritou (tacitní-explicitní) poskytuje možnost lépe porozumět vztahu praktických zkušeností studentů a pedagogické teorie, k níž se postupně dopracovávají ve spolupráci se svými vzdělavateli.

Pojem tacitní znalosti je dosud obtížně uchopitelný. Je to jednak proto, že dosud není zcela jednoznačně tento pojem vymezen, ale jednak také proto, že se již velmi dlouhou dobu soustřed'ujeme na epistémé, tj. na diskursivní poznatky (teorii) odděleně od praxe. Považujeme proto za potřebné uchopit tacitní znalosti kontrolovanějším způsobem. Vyjasnit, které tacitní znalosti jsou pro budoucího učitele „užitečné“ (závažné, klíčové) a které jsou méně významné. Na klíčové tacitní znalosti se potom soustředí pozornost jak vzdělavatelů učitelů, tak jejich studentů ${ }^{12}$.

V této studii jsme se zabývali především kognitivní stránkou tacitních znalostí. Tacitní znalosti se však netýkají pouze mysli, ale celého těla. Vždyt' i zkušenosti (znichž se tacitní znalosti odvíjejí) nemají pouze složku verbální, ale i neverbální - tělovou. V jednání (budoucího) učitele se proto propojuje dimenze (kompetence) psychodidaktická s dimenzí (kompetencí) psychosomatickou (Švec, 2009c). Na některé možnosti posilování psychosomatické dimenze v přípravě budoucích učitelů jsme již poukázali (Švec, 2011b). Přesto se ukazuje naléhavá potřeba tuto dimenzi tacitních znalostí podrobit hlubšímu zkoumání.

Tacitní znalosti v pedagogické přípravě budoucích učitelů nejsou dosud doménou, které je věnována pozornost $\mathrm{v}$ rovině praktické a teoretické. Pocitujeme absenci výzkumu tacitních znalostí studentů učitelství. Proto jsme připravili projekt výzkumu, který bude hledat odpověd' na otázku, jak

12 Dalším pojmem, který se objevuje na pedagogické scéně, je pojem profesní vidění (budoucích) učitelů (Minaříková \& Janík, 2012). Domníváme se, že souvisí s tacitními znalostmi. Lze totiž předpokládat, že podstata profesního vidění je tacitní. 
se utvářejí tacitní znalosti studentů v průběhu jejich pedagogické praxe na školách ${ }^{13}$. Předpokládáme, že:

- tacitní znalosti zahrnují dvě základní složky: kognitivní (mentální obraz činnosti) a non-kognitivní (motivaci k činnosti) ${ }^{14}$;

- $\quad$ tacitní znalosti se odvíjejí ze studentovy subjektivní teorie výuky, která se v průběhu pedagogické praxe proměňuje;

- tacitní znalosti studentů učitelství se utvářejí vnímáním a řešením praktických situací, životními zkušenostmi, experimentováním, improvizací a tvořivým řešením problémových situací;

- $\quad$ i když si studenti učitelství osvojují tacitní znalosti samostatně, relativně bez cizí pomoci, je žádoucí poskytnout jim vnější oporu a zpětnou vazbu; utváření tacitních znalostí usnadňuje sdílení zkušeností studentů se vzdělavatelem učitelů nebo zkušeným cvičným učitelem na praxi;

- tacitní znalosti se utvářejí při hlubokém osobním a emocionálním zaujetí řešeným problémem; předpokládáme, že k takovému zaujetí dochází zejména v neočekávaných situacích, s nimiž se student setkává v průběhu pedagogické praxe;

- významným prvkem v procesu utváření tacitních znalostí je sebereflexe, nebot' umožňuje, aby si student učitelství tyto znalosti (nebo alespoň jejich podstatnou část) uvědomil a zexplicitnil.

\section{Literatura}

Bendl, S. et al. (2011). Klinická škola: místo pro výzkum a praktickou přípravu budoucích učitelü. Praha: Univerzita Karlova, Pedagogická fakulta.

Bengtsson, J. (1993). Theory and practice: Two fundamental categories in the philosophy of teacher education. Educational Review, 45(3), 205-211.

Burbules, N. C. (2008). Tacit teaching. Educational Philosophy and Theory, 40(5), 666-676.

Cianciolo, A. T., Mattthew, C., Sternberg, R. J., \& Wagner, R. K. (2006). Tacit knowledge, practical inteligence, and expertise. In K. A. Ericsson, N. Charness, P. J. Feltovich, \& R. R. Hoffman (Eds.), The cambridge handbook of expertise and expert performance (s. 613-632). Cambridge: Cambridge University Press.

de Vries, R. E., van den Hooff, B., \& de Ridder, J. A. (2006). Explaining knowledge sharing. Communication Research, 33(2), 115-135.

13 Švec, V. a kol. (červen 2012). Osvojování tacitních znalostí studenty učitelství v průběhu jejich pedagogické praxe. Návrh projektu do GA ČR.

$14 \mathrm{Na}$ tuto skutečnost je i v literatuře velmi omezeně poukazováno. Přitom zkoumání nonkognitivní stránky tacitních znalostí je další výzkumnou doménou. 
Durrance, B. (1998). Some explicit thoughts on tacit learning. Training \& Development, 52(12), 24-29.

Drever, E., \& Cope, P. (1999). Students' use of theory in an initial teacher education programme. Journal of Education for Teaching, 25(2), 97-109.

Gregar, A. et al. (2011). Tacitní znalosti a úspěšné rrízení. Martin: Alfa print.

Hančil, J. (2010). K diváckým strategiím dialogického jednání. Disk, 34(prosinec). Dostupné zhttp://casopisdisk.amu.cz/cs/archiv/rocnik-2010/aktualni-cislo/k-divackym-strategiim -dialogickeho-jednani.

Ipe, M. (2003). Knowledge sharing in organizations: A conceptual framework. Human Resource Development Review, 2(4), 337-359.

Janík, T., \& Havel, J. (Eds.). (2005). Pedagogická praxe a profesní rozvoj studentů. Brno: Masarykova univerzita.

Korthagen, F., Kessels, J., Koster, B., Lagerwerf, B., \& Wubbels, T. (2011). Jak spojit teorii s praxí: Didaktika realistického vzdělávání učitelů. Brno: Paido.

Lukášová, H. (2006). Metamorfózy pojetí učitelské přípravy a jejich pedagogický výzkum. Pedagogika, 56(1), 5-18.

Maňák, J. (2011). K problému teorie a praxe v pedagogice. Pedagogická orientace, 21(3), 257-271.

Mascitelli, R. (2000). From experience: Harnessing tacit knowledge to achive breakthrough innovation. Journal of Product Innovation Management, 17(3), 179-193.

Minaříková, E., \& Janík, T. (2012). Profesní vidění učitelů: od hledání pojmu k možnostem jeho uchopení. Pedagogická orientace, 22(2), 181-204.

Nonaka, I., \& Takeuchi, H. (1995). The knowledge-creating company: How Japanaese companies create the dynamics of innovation. Oxford: Oxford University Press.

Nikkanen, P., \& Kantola, J. (2008). How to capture tacit knowledge? Proccedings of the ECER VETNET Conference 2008: From Teaching to Learning (Gothenburg, 10 to 12 September 2008). [www.ecer-vetnet.wifo-gate.org]

Polanyi, M. (1966). The tacit dimension. New York: Doubleday \& Company.

Píšová, M. (2010). Učitel - expert. Přehled výzkumných trendů a jejich výsledků. Pedagogika, 60(3-4), 242-253.

Shulman, L. S. (1998). Theory, practice, and the education of professionals. The Elementary School Journal, 98(5), 511-526.

Slavík, J. (2009). Symptomy estetična v intersubjektivně sdíleném poznání. In D. Krámský (Ed.), Kognitivní věda dnes a zítra (s. 219-232). Liberec: Bor.

Slavík, J., Janík, T., Najvar, P., \& Píšová, M. (2012). Mezi praxí a teorií v učitelském vzdělávání: na okraj českého překladu knihy F. A. J. Korthagena et al. Pedagogická orientace, 22(3), 367-386.

Spilková, V. (2006). Dilemata v pojetí pedagogické přípravy studentů učitelství. Pedagogika, 56(1), 19-30.

Sternberg, R. J. (1999). Epilogue: what do we know about tacit knowledge? In R. Sternberg \& J. A. Horvath (Eds.), Tacit knowledge in professional practice (s. 231-236). London, New Jersey: Lawrence Erlbaum Associates.

Sternberg, R. J. (2004). Múdri nie sú hlúpi, ale môžu byt’ nerozumní. In J. Sternberg (Ed.), Prečo robia múdri l'udia hlúposti? (s. 269-280). Bratislava: Ikar. 
Sternberg, R. J., \& Horvath, J. A. (Eds.). (1999). Tacit knowledge in professional practice. London, New Jersey: Lawrence Erlbaum Associates.

Švec, V. (2002). Faktory ovlivňující rozvoj pedagogických dovedností studentů. Pedagogická orientace, $12(1), 63-82$.

Švec, V. (2005). Studium implicitních pedagogických znalostí jako inspirace pro osobnostní přípravu učitelů. In V. Švec (Ed.), Od implicitních teorií výuky k implicitním pedagogickým znalostem (s. 27-40). Brno: Paido.

Švec, V. (2008). Objevování psychosomatických disciplín. In Psychosomatické disciplíny v př́ípravě pedagogů: východiska a první zkušenosti (s. 35-45). Brno: Paido.

Švec, V. (2009a). Sdílení znalostí ve školním prostředí. Pedagogická orientace, 19(2), 22-37.

Švec, V. (2009b). Př́ípravné vzdělávání učitelů. In J. Průcha (Ed.), Pedagogická encyklopedie (s. 408-412). Praha: Portál.

Švec, V. (2009c). Intervence do procesu utváření didaktických znalostí obsahu: inspirace teorií jednání. In T. Janík, et al., Možnosti rozvíjení didaktických znalostí obsahu u budoucích učitelů (s. 45-56). Brno: Paido.

Švec, V. (2011a). Tacitní znalosti v činnosti profesionálů. In A. Gregar, et al. Tacitní znalosti a úspěšné ř́zení. (s. 13-25). Martin: Alfa print.

Švec, V. (2011b). Hra, zkušenost, kondice a jednání v přípravě profesionálů veřejně působících. In Psychosomatické disciplíny v teorii a praxi (s. 123-139). Praha: Akademie múzických umění.

Švec, V., \& Musil, R. (1999). Pokus o změnu přístupu k osvojování pedagogických vědomostí a dovedností studentů učitelství (ve výuce obecné didaktiky). In T. Svatoš (Ed.), Poslední desetiletí v českém a zahraničním pedagogickém výzkumu (s. 268-274). Hradec Králové: Česká asociace pedagogického výzkumu a Pedagogická fakulta VŠP.

Tobin, K., \& Roth, W-M. (2006). Teaching to learn: A view from the field. Rotterdam: Sense Publishers.

Zanting, A., Verlop, N., \& Vermunt, J. D. (2003). Using interviews and concept maps to access mentor teachers' practical knowledge. Higher Education, 46(2), 195-214.

\section{Autor}

prof. PhDr. Vlastimil Švec, CSc., Masarykova univerzita, Pedagogická fakulta, Katedra pedagogiky, Poříčí 31, 60300 Brno, e-mail: svec@ped.muni.cz

\section{Tacit knowledge as a bridge between theory and practice in the domain-general aspect of teacher education}

Abstract: The paper deals with tacit knowledge in the pedagogical component of teacher education. Tacit knowledge is seen - metaphorically - as a bridge between theory and practice. In the paper, the concept of tacit knowledge is characterised; it is a concept that has not been much discussed in Czech literature on education. Tacit 
knowledge is seen as personal and individual; it is developed through the subject's experience and has the following characteristics: it is procedural in nature and can be difficult to express, it is relevant for achieving aims that are considered important, it is developed with just little help of others or without such help whatsoever, it is bound to a specific context. In teacher education, a student teacher develops tacit knowledge through dealing with practical situations. In order for tacit knowledge to develop and improve in students, it must first be made explicit. One of the tools that help make tacit knowledge explicit is self-reflection, which however by itself is not enough for the student to realise what his or her behaviour is and how it can be improved. Such aim can be achieved through sharing experience and tacit knowledge between students and teacher educators (mentors, field didacticians, etc).

Keywords: theory and practice, tacit knowledge, self-reflection, sharing tacit knowledge, teacher education

Starý, K., Dvořák, D., Greger, D., \& Duschinská, K. (2012). Profesní rozvoj učitelü. Praha: Karolinum.

V zahraničních výzkumech, jejichž přehled mimo jiné najdete v této knize, se již delší dobu ozývá volání po tom, aby se účinky profesního rozvoje učitelů posuzovaly podle skutečných dopadů na výsledky jejich pedagogické práce. Informace o aktivitách profesního rozvoje učitelů v České republice jsou bohužel fragmentární, často chybí mezinárodní srovnání, a pokud už nějaká existují, je jim věnována nedostatečná pozornost ze strany vzdělávací politiky. Spatřujeme v tom i jednu z možných příčin klesajících výsledků českých žáků v mezinárodních šetřeních. Cílem knihy je přispět k odborné diskusi o kvalitě práce učitelů aktuálními informacemi o různých cestách jejich profesního rozvoje. Panuje shoda, že kvalitní př́ípravné vzdělávání může zajistit dobrý základ pro výkon učitelské profese, ale skutečného mistrovství lze dosáhnout až v průběhu profesní dráhy. Absence systematické podpory v profesním vzdělávání a jasných profesních perspektiv $\mathrm{v}$ podobě kariérního řádu nevytváří motivující prostředí pro profesní růst. Ukazuje se také, že tradiční pojetí profesního vzdělávání formou absolvování různých školení a kurzů je v současnosti doplňováno o nové formy, jako jsou sdílený odborný diskurs na pracovišti, mentoring či řízené samostudium, které čerpají z reflexe profesních zkušeností. Na základě analýzy sekundárních i dílčích primárních pramenů si dovolujeme v závěru vyslovit určitá doporučení, na co by se v profesním rozvoji učitelů měl klást větší důraz a jaké formy podpory by to umožnily. Vhodnou kombinací vnější podpory učitele a vnitřní zodpovědnosti učitele za vlastní profesní zrání a předávání profesních zkušeností lze zvýšit kvalitu práce učitelů. 